\title{
Internal corporate venture planning autonomy, strategic evolution, and venture performance
}

\author{
Jeffrey G. Covin • Robert P. Garrett Jr • \\ Donald F. Kuratko $\cdot$ Mark Bolinger
}

Accepted: 3 June 2019

(C) Springer Science+Business Media, LLC, part of Springer Nature 2019

\begin{abstract}
Theory and research typically suggest that internal corporate (ICV) venture managers should be granted the freedom needed to manage their new business initiatives as they choose, with little or no interference from senior levels of corporate management. The current research investigates the relationship between venture planning autonomy and venture performance, arguing that this relationship is affected by the types (i.e., goal related or value proposition related) and levels (low-to-high) of strategic evolution occurring in the ICV. Data collected from 145 ICVs operating in 72 corporations indicate that venture planning autonomy is most positively related to venture performance when those ICVs' goals remain stable over the course of venture operations, but the value propositions of those ICVs are evolving.
\end{abstract}

J. G. Covin $(\bowtie) \cdot$ D. F. Kuratko $\cdot$ M. Bolinger

Kelley School of Business, Indiana University, Bloomington, IN 47405, USA

e-mail: covin@indiana.edu

D. F. Kuratko

e-mail: dkuratko@indiana.edu

M. Bolinger

e-mail: markboli@iu.edu

R. P. Garrett Jr,

College of Business, University of Louisville, Louisville, KY

40292, USA

e-mail: robert.garrett@louisville.edu
Keywords Entrepreneurship · Corporate entrepreneurship $\cdot$ Performance $\cdot$ Planning autonomy

\section{JEL classification L26}

\section{Introduction}

Internal corporate ventures or ICVs are new businesses founded within pre-existing corporate structures. The success of ICVs is often discussed as predicated upon how well two fundamental venture-related needs are met during the venturing process. Specifically, anecdotal evidence and decades of research identify the needs for (1) venture planning autonomy and (2) experiencebased strategic evolution as critical success factors for ICVs (see Bouchard and Fayolle 2018; Hill and Georgoulas 2016). Venture planning autonomy-that is, venture planning-related decision-making vested at the level of venture managers, rather than at higher corporate levels - is often beneficial because it places decision-making responsibility and authority in the hands of those individuals best positioned to directly observe and manage the venture. Experience-based strategic evolution - that is, changes to the venture's goals and/or strategies enacted as knowledge accumulates over the course of venture operations - is often beneficial because ICVs are essentially experiments. Venture goals and/or strategies often need to be changed as those managing the venture discover what elements of the initial strategic template are or are not "working." 
Past research in the ICV area has explored autonomy and strategic evolution-related matters as essentially independent phenomena. We argue that these are inherently interdependent considerations and that one cannot separate the matter of the value of planning autonomy from the matter of an ICV's likely need for eventual strategic evolution. In particular, we argue that "who" is making strategic changes interacts with "what" strategic changes are being made to drive venture performance. Results based on a sample of 145 ICVs in 72 parent corporations indicate that high venture planning autonomy benefits venture performance most when ventures are pursuing stable goals, yet their value propositionsi.e., intended bases for market appeal, such as superior quality and low price- have evolved.

The current research makes two principal contributions to the corporate venturing literature. First, this research demonstrates the context-specific value of venture planning autonomy. Existing research on this topic generally recognizes that venture managers should be granted the freedom to manage their businesses as they see fit (e.g., Leten and Van Dyck 2012). This common observation is based on the assumption that knowledge gained through direct involvement in venture operations places front-line venture managers in the best positions to comprehend the needs of and formulate venture strategy. However, beyond this broad observation, past research does a poor job of identifying when or why planning autonomy might variously matter as a driver of venture performance. The current research demonstrates that the degree and object of a venture's strategic evolution - that is, evolution of the venture's goals or evolution of the venture's value proposition - affect the planning autonomy-performance relationship.

A second principal theoretical contribution of this research is its highlighting of the aforementioned interdependency matter. That is, "who" is doing the planning for ICVs - corporate-level senior managers, venturelevel managers, or some combination that represents shared responsibility for venture planning-becomes increasingly or decreasingly relevant to venture performance as a function of "what" about the venture's strategic posture - the goals or the value proposition of the venture - is being changed over the course of venture operations. Results suggest that venture-level managers are particularly adept at recognizing and implementing performance-enhancing value proposition changes over the course of venture operations. In scenarios of goal evolution, however, venture-level managers are no more successful than corporate-level managers at choosing new goals for the venture that promote venture performance. Moreover, the scenario of stable venture goals, unlike the case with stable value propositions (Covin et al. 2015), is associated with superior venture performance, and performanceenhancing stable goals are more likely to have been chosen by venture-level managers.

\section{Theoretical background}

The phenomena of venture planning autonomy and strategic evolution are common foci of internal corporate venturing theory and research. The position often taken in the ICV literature is that venture planning autonomy promotes venture performance because it places strategic decision-making responsibility and authority in the hands of individuals who are most likely to understand and effect positive changes within the new business context due to their direct and ongoing involvement with venture operations (Gard et al. 2018; George and MacMillan 1985; Ginsberg and Hay 1994; Leten and Van Dyck 2012). Strategic evolution-or changes to what the venture is trying to achieve, or how it is trying to achieve it - is, likewise, discussed as essential to venture success inasmuch as ICVs must "learn their way in" to the market, and the knowledge gained through venture operations will often suggest the advisability of changing venture goals and/or their associated strategies (Bhide 1994; McGrath et al. 2006; Weiss 1981). Still, much of the empirical research pertaining to these planning autonomy and strategic evolution matters is anecdotal (for recent reviews of internal corporate venturing research see Covin et al. 2015 and Hill and Georgoulas 2016). Moreover, while the majority of the prior theorizing and empirical research points to the benefits of venture planning autonomy and strategic evolution, prior research is certainly not uniform in the arguments advanced and findings observed.

For example, in a conceptual essay, Simon et al. (1999) argued that while venture planning autonomy is generally warranted, too much autonomy can lead to diminished ICV performance. Their argument was that autonomy must be balanced with control and oversight provided by corporate management in order to extract maximum value from new business initiatives. Additionally, while research by Gard et al. (2018) documented the commonly argued positive effect of 
"strategic autonomy" - defined as "the authority delegated to venture managers on decisions that can influence strategic outcomes without obtaining prior approval from corporate management" (p. 3) - on ICV performance, other large-sample empirical research has yielded different results. In their study of 97 ICVs, Thornhill and Amit (2001) hypothesized and found that various indicators of venture autonomy-including, for example, the "relative decision making authority of venture managers and employees, the level of identification of employees relative to parent or venture, and the perceived sense of autonomy of the venture from the parent"-are associated with lower performing ventures. Likewise, Johnson's (2012) study of 38 ICVs reported as negative effect on venture performance of planning autonomy - defined as "the extent to which the venture's management team is responsible for establishing goals, timetables, and strategy for the venture" (p. 470). In her study of 56 ICVs, McGrath (2001) reported a modest negative main effect on learning effectiveness - an ICV performance indicator - of goal autonomy (defined as "the extent to which a project team was granted autonomy with respect to goals, roles, and authority structures" [p. 122]) and no significant main effect on learning effectiveness of supervision autonomy (defined as "the extent to which a project team was granted autonomy with respect to operating activities" [p. 122]). Similar to McGrath's results pertaining to supervision autonomy, research by Garrett and Neubaum (2013) on 145 ICVs reported no significant effect on venture performance of a more operational (versus planning-related) dimension of autonomy-namely, operations autonomy. Garrett and Neubaum (2013, p. 899) defined operations autonomy as "the extent to which the venture's management team (versus corporate parent management) is responsible for the design and control of the venture's internal operations."

With respect to research on strategic evolution, scholars have noted that the exploratory nature of new ventures will typically necessitate some degree of change to the venture's goals or strategies during the conduct of business operations. For example, Bhide (1994, p. 161) observed "businesses cannot be launched like space shuttles, with every detail of the mission planned in advance. Initial analyses only provide plausible hypotheses, which must be tested and modified. Entrepreneurs should play with and explore ideas, letting their strategies evolve through a seamless process of guesswork, analysis, and action." Similarly, Garvin and Levesque (2006, pp. 105-106) stated "The high levels of ambiguity in new businesses imply that corporate entrepreneurs won't get it right the first time. Because hard numbers are difficult to come by and strategic options are difficult to identify, past practices, too, offer little guidance. Experimentation is essential. Managers must begin with hypotheses about what will work and what won't; then, they should search for ways of validating or invalidating their preconceptions, knowing that first-cut strategies will change over time."

Still, large-sample empirical research on the matter of strategic evolution's effect on ICV performance is relatively rare. Exceptions include research by Covin and his colleagues. Specifically, Covin et al. (2015) reported an inverse U-shaped relationship between ICV value proposition evolution - defined as "the extent to which the intended basis on which the ICV will appeal to its target market changes over time" (p. 750)-and venture performance. Covin et al. 2018 reported a negative linear effect of ICV goal evolution-defined as "the extent to which an ICV's strategic objectives evolve over the course of the ICV's development" (p. 7)-on venture performance. Significantly, neither of these studies explored the important matter of who is making these strategic changes - senior corporate managers, venture managers, or some combination thereof-as a factor likely determining the effect of those changes on venture performance.

\section{Hypotheses}

3.1 Venture planning autonomy and venture performance

Given that ICVs are "new businesses" to their corporations, it may be unreasonable to expect that corporate parents will necessarily or even generally be able to add significant value to ICV operations through their involvement in venture planning. The "newness" of ICVs to their corporate parents creates opportunities for venture mismanagement on the corporate parent's part because, for example, parent knowledge of the drivers of success in the ICV's product-market arena will often be weak or poor (Zook et al. 2001). The scenario of parent unfamiliarity with their ICVs' operations provides a rationale for advocating that planning autonomy generally be granted to new ventures. In short, every time a 
parent founds an ICV it is, by definition, starting a new business, and the new business status of ICVs suggests that the corporate parents may not know a lot about how to manage those ICVs. Because ICVs are, by definition, exploring markets and/or products significantly different from those of their parent corporations, the parent corporation's knowledge, structures, policies, and practices may not be appropriate or relevant in the new competitive domain (Simon et al. 1999).

Moreover, entering new domains commonly requires that venture management learn through experimentation (Bhide 2000; Garvin and Levesque 2006), and experimentation often demands a great deal of managerial discretion and autonomous action (Weiss 1981). Because of the experimental nature of ICVs, they often pursue strategies that require a high degree of decisionmaking flexibility (Block and MacMillan 1993), and autonomy allows venture management to adapt and customize the venture to its competitive domain (Birkinshaw and Hill 2005). The experimental nature of ICVs necessitates that they learn about their business through their operations (learning-by-doing) and strategically adapt as necessary. Venture planning autonomy grants venture managers flexibility to enact new plans and decisions as the domain of the ICV becomes better understood. Importantly, venture planning autonomy places strategic decision-making authority in the hands of those who are likely most knowledgeable about matters pertaining to the venture's operations and competitive positioning. Thus, it is hypothesized:

H1: Venture planning autonomy is positively related to venture performance.

\subsection{Moderating effects of strategic evolution}

Venture planning autonomy is recognized as particularly important to venture success when the parent corporation has little direct value to add to the venture, as might be the case, for example, if the parent is unable to provide any critical knowledge- or property-based resources to the venture (and therefore parent involvement in the venture's affairs is tantamount to meddling) (e.g., Glaister et al. 2003). We argue that there are additional, venture strategy-related considerations - the extensiveness of changes to the venture's goals and value propositions, in particular - that are unrecognized as factors affecting the planning autonomy-venture performance relationship, yet that may be equally as relevant to this relationship as the parent's possible provision of strategic resources. Our reasoning follows.

Goals with at least a minimal degree of clarity and specificity must be established early in an ICV's existence to guide venture operations. However, given the inherently experimental and exploratory nature of ICVs, corporate and venture managers will not necessarily know how those venture goals can be best achieved, or even if the established goals are realistic. As such, there will always be some learning that takes place over the course of venture operations about the content of venture goals and the avenues for and/or appropriateness of their pursuit (Burgelman 1988; McGrath 1995). Based on the knowledge that accumulates as venture operations are conducted, venture goals may be held relatively constant over time, or they may be modified, becoming more (or less) clear, specific, and ambitious. Substantively different goals may also emerge over the course of venture operations, such as goals that might be established for products not originally offered or markets not originally targeted by the ICV. We argue that the relative stability of venture goals has implications for the degree of venture success likely to be associated with venture planning autonomy.

In particular, stable venture goals are likely to increase the effectiveness of venture planning autonomy because such goals enable venture managers to exhibit consistent, sustained attention to this important strategic consideration. Such attention fosters understanding of the implications of the venture's goals and their potential viability, along with the possible strategic paths through which they may be achieved. Moreover, the fact that stable goals have, by definition, remained constant likely indicates their workability for the venture, with commitment to these goals potentially increasing as those responsible for their establishment work to ensure their realization, as would be the case in the presence of high venture planning autonomy. Significantly, theory and research suggest that involvement in the goal setting process is positively associated with goal commitment, and goal commitment promotes goal achievement. (Klein et al. 1999; Locke et al. 1988). Managerial perceptions of the venture's performance level will be associated with the extent to which the venture's goal(s) have been achieved.

Venture goals that evolve may do so because those responsible for their (re)establishment recognize some flaw or limitation inherent to their prior content. 
Evolving venture goals diminish or negate the benefits of venture planning autonomy because "new" goals that are chosen by venture managers may be only marginally more viable or appropriate than "new" goals established for the venture by corporate management. Venture managers granted planning autonomy will have a better sense than corporate managers regarding why and how the new goals were chosen, given that the venture managers are personally responsible for their selection. However, in order for ventures to perform well the implications of these new goals for the conduct of venture operations must still be identified and acted upon. Policies, decisions, and resource allocations implied by or supportive of the new goals will need to be chosen and tested, with the means through which the new goals might be realized only clarifying over time through a process of action and discovery.

In short, venture managers who are granted planning autonomy might be expected to know and embrace venture goals they reformulate better than goals reformulated for them by corporate managers. However, venture managers' familiarity and commitment to their ICVs' reformulated goals does not negate the need for sustained attention to those goals and their resource and operational implications in order to verify their defensibility and ensure their realization (Garud and Van De Ven 1992). Such sustained attention is difficult or impossible to achieve if the venture's goals keep changing. Thus, when venture goals change the matter of who changed them may still affect their realization, but what may matter more is the challenge of uncovering the means through which they can be realized. Discovery and demonstration of the means through which goals can be realized is inherently a trial-and-error process that unfolds over time and is made more efficient through the cumulative learning facilitated when goals remain stable (Lynn et al. 2000).

H2: The relationship between venture planning autonomy and venture performance is more positive when venture goal evolution is low than when venture goal evolution is high.

Internal corporate ventures typically experience some degree of "strategic evolution" over the course of their operations. This can occur, for example, in the form of changing goals, as discussed above, and/or changes in the means through which those goals are pursued - that is, the venture's business strategy
(Bhide 2000; Burgelman 1988). A core component of business strategy is its value proposition, or the basis on which the business intends to appeal to the market, thus generating demand for its products and services (Osterwalder et al. 2014; Payne et al. 2017). For example, an ICV may have a market offering whose intended appeal is some form of technological superiority, or low price, or high quality, or any number of differentiating factors the corporate and/or venture managers assume will generate market demand. We argue that just as the relative stability of venture goals has implications for the degree of venture success likely to be associated with venture planning autonomy, so too does the relative stability of the venture's value proposition. However, unlike the case with venture goals, changes rather than stability in the venture's value proposition should enhance the positive effects of venture planning autonomy on venture performance.

To understand why venture value position evolution will likely have the opposite effect of venture goal evolution on the planning autonomy-performance relationship, one needs to again reflect on why and how planning autonomy is likely to benefit venture performance. Planning autonomy places decision responsibility in the hands of those closest to and most knowledgeable of the venture's day-to-day operations - i.e., the venture managers. The value that might be contributed by these managers to their ICVs' operations occurs as a function of the degree to which they adapt and modify their ventures' strategies in accommodation of first-hand knowledge gained over the course of venture operations. These venture managers are not once-removed in a structural sense from venture operations, as are senior corporate managers. Rather, venture managers are positioned to more immediately and directly observe the enactment and consequences of venture strategic decisions. This closeness to the "action" of the ICV that exists at the level of venture management enables these managers to well recognize the need for changes in tactics - including changes to the venture's value proposition - that may be warranted given the venture's progress (or lack thereof) toward goal attainment (Kuratko et al. 2009; Sykes 1986). Thus, any changes these managers make to the venture's value proposition will likely be well informed and appropriately motivated.

The preceding suggests that venture planning autonomy benefits venture performance because when adaptions to the ICV's strategy need to be made - and they 
will almost always need to be made (Kiss and Barr 2015; Piercy 2016) - those making the changes will be the level of managers most knowledgeable of reasons for the underperformance of past strategic choices as well as the potentially superior strategic options that may be under consideration. Thus, the scenario of stable value propositions diminishes or negates one of the key benefits of autonomy-i.e., having strategic changes being decided upon and enacted by those closest to and most informed about the venturing action. Conversely, the scenario of evolving value propositions is one in which the benefits of venture planning autonomy are best captured because the changes enacted are being selected and implemented by managers responsible for and most knowledgeable of those changes.

H3: The relationship between venture planning autonomy and venture performance is more positive when venture value proposition evolution is high than when venture value proposition evolution is low.

\section{Methods}

\subsection{Sample}

Because internal corporate venturing is an activity not typically identifiable through public sources, an initial target sample for this study was chosen based on the potentiality for those firms to have been engaged in this activity. All initially targeted firms were included in the Dun and Bradstreet Million Dollar Database. Several additional criteria were adopted in choosing the firms approached for possible involvement in the study. First, the targeted firms had to be manufacturing based, a criterion chosen because product technologies are often leveraged to diversify firms into new business arenas. Second, the targeted firms had to have annual sales revenue of at least $\$ 50$ million, a criterion chosen because internal corporate venturing is less typical among smaller than larger firms. Finally, the targeted firms were all headquartered in the American Midwest (eight states, in total), a criterion chosen because personal visits to the participating corporations would be required and reasonable physical proximity of the targeted firms to the research team would be important to controlling data acquisition costs.
In total, 496 corporations met the initial screening criteria. Phone contacts (or contact attempts) with representatives from these firms were used to ascertain their possible involvement in internal corporate venturing activity and interest in participating in the study. Two hundred and forty-three of the firms were unresponsive to the initial contact attempts, 85 of these firms indicated no interest in participating in the study, and 58 of these firms indicated interest in the study, but they were not involved in any internal corporate venturing activity (using the strict definition of this activity described below). A total of 110 firms expressed an interest in the study and were (or had previously been) engaged in internal corporate venturing.

The research team was able to schedule face-toface visits with the persons who oversaw internal corporate venturing activity in 85 of the 110 firms. During these visits, the complete scope of the research was explained and research materialsvarious survey forms-were distributed. Materials were eventually received from 80 firms, eight of which furnished incomplete data or data suggesting their inappropriateness for the study (e.g., the firm was engaged in minor product development efforts, but not new business activity), leaving a set of 72 firms in the final sample. These parent corporations had a mean of 10,910 employees (s.d. $=30,196)$ and $\$ 5.5 \mathrm{~B}$ in sales revenue (s.d. $=\$ 14.8 \mathrm{~B})$. These same data for the firms that were initially contacted but that did not participate in the study were $453 \mathrm{em}$ ployees (s.d. = 937) and \$1.8B (s.d. = \$9.0B). A significant difference exists in the size indicators $(p<.01$ in both cases) for these two groups. The fact that the nonparticipating firms are, on average, significantly smaller than the participating firms may be attributable to the possibility that these smaller firms were simply not engaged in internal corporate venturing and, therefore, chose to not participate in a study that was irrelevant to them.

Data were collected from 145 ICVs operating within this set of 72 parent corporations. One hundred and nineteen of the ICVs were currently operating as of the time of the data collection, and 26 were defunct (i.e., they had failed or were otherwise terminated in the previous 7 years). The mean age of these ICVs was 3.1 years (s.d. $=2.1$ years). The mean number of employees was 20.7 (s.d. $=51.5$ ). 


\subsection{Data collection}

Data were collected from both the corporate-level managers who were responsible for overseeing internal corporate venturing activities in their firms as well as from individual venture managers in those firms. Three separate survey instruments were employed. The corporate managers completed a survey concerning background information on the parent company as well as separate surveys focused on descriptive data for each participating venture within their corporations. Venture managers completed a survey pertaining to their management practices.

Corporate-level managers were asked to choose ventures for possible participation in the study based on several criteria. First, the venture must have been identifiable as a new business for the corporation, based on the new business identification matrix proposed by Morris et al. (2011). Briefly, this matrix plots the "newness" of a venture to the corporation along product and market dimensions (see Appendix Table 4). Second, consistent a commonly employed (albeit arbitrary) age constraint (e.g., Wiklund et al. 2010), the venture had to be no more than 7 years old. Third, to avoid a (high) performance bias in the venture sample, in corporations where all new ventures were not offered as candidates for inclusion in the study, the corporate managers were asked to select a set of their ICVs that had performed variously well (in the opinions of those corporate managers). Fourth, to avoid a survivor bias in the venture sample, corporate managers were asked to consider their firms' defunct ventures - those that had failed or were otherwise terminated over the past 7 years - for possible inclusion in the sample. Finally, corporate managers were asked to identify ICVs operating at various stages of development where, consistent with Thornhill and Amit (2001), early-stage ventures were operationalized as those having received initial funding from their parent corporations, but which has not yet generated any sales revenue $(n=37)$; middle-stage ventures were generating sales revenue but were not yet profitable $(n=52)$; and established-stage ventures were profitable $(n=56)$.

\subsection{Measures}

Measures of the main constructs relevant to this study can be found in Appendix 2. Mean scoring was used to compute values of the research variables.

\subsubsection{Dependent variable}

Venture performance was assessed using a four-item scale previously employed by Johnson (2012). This subjective measure was chosen because it captures managers' overall assessment of ICV performance, recognizing that ICVs can be founded with different specific purposes in mind. Also, any given performance criterion may not be relevant for ICVs operating at different development stages. For example, early-stage ventures are - as operationalized in the current research and consistent with Thornhill and Amit (2001) — not profitable, so a profitability-related criterion would not be appropriate for assessing their performance. Significantly, the venture performance was assessed by the corporate managers who oversaw venturing activity in their firms, whereas the independent variables were assessed by the managers in charge of the ventures being studied. Thus, common source bias is not a concern in the current research.

\subsubsection{Independent variables}

The venture planning autonomy scale employed in the current research was also previously employed by Johnson (2012). Low mean scores on the items of this scale indicate that the assessed planning-related activities and decision areas are the responsibility of higher levels of authority within the parent corporation; high mean scores indicate that the activities and decision areas are the responsibility of the venture managers; and intermediate scores indicate various degrees of mixed or shared responsibility.

Venture goal evolution and venture value proposition evolution were assessed using scales previously employed by Covin et al. (2018) and by Covin et al. (2015), respectively. A low goal evolution score indicates that the venture's objectives have not changed much since they were initially established, and a high score suggests the opposite. Likewise, a low value proposition evolution score indicates that the venture's value proposition has not changed much since it was initially established, and a high score suggests the opposite.

\subsubsection{Control variables}

Thirteen venture-level control variables and six corporate-level control variables were employed in the current research. Starting with the venture level, 
although venture value proposition evolution is assessed as a moderator in the current research, the square of this term has been found to affect venture performance in prior research by Covin et al. (2018). Specifically, an inverse U-shape relationship between venture value proposition evolution and performance was observed in this prior study. Accordingly, the square of the venture value proposition score was treated as a control variable in the current research. Venture development stage was controlled using the aforementioned classification scale proposed by Thornhill and Amit (2001). Size of the venture was controlled using number of venture employees as the indicator. Venture age was controlled, measured as number the years since the corporation had initially (financially) invested in the venture. Market focus and product focus of the venture were controlled based on where the venture was positioned within the ICV identification matrix (see Appendix Table 4). To account for the favorability of the external environment into which the venture was launched, measures of environmental dynamism and environmental hostility were employed as control variables. Dynamism as assessed using Miller and Friesen's scale (1982), albeit with a slightly modified response format. Covin et al.'s (2000) scale was used to assess environmental dynamism. Recognizing that the degree to which an ICV's goals and value proposition evolve may be related to the initial clarity of these matters, initial goal clarity and initial value proposition clarity were also controlled in the current study, using the measures of these variables appearing in Covin et al. (2018) and Johnson (2005), respectively.

Three final venture-level control variables were included because they have been shown in prior research to affect venture performance. Specifically, research by Garrett and Neubaum (2013) revealed that ICV performance is positively affected by a venture's initial strategic asset endowment - defined as "the extent to which the venture's strategic assets - i.e., the key knowledge, technologies, competencies, and other resources needed to excel in the venture's business-were possessed, controlled, or owned by the venture at its early development stage" (p. 898) — as well as by the degree of top management support given to the venture, defined as “the corporate parent's senior-level executives' support of and commitment to the ICV's success" (p. 898). The scales for these initial strategic asset endowment and top management support variables appearing in Garrett and Neubaum (2013) were employed in the current research.
Lastly, venture operations independence - defined by Garrett and Covin (2015, p. 764) as "the extent to which structural or process linkages exist between the venture's operations and those of the corporate parent's other businesses"-was included as a control variable. Prior research by Garrett and Covin (2015) revealed that while venture operations independence has no significant main effect on venture performance, the interaction of venture operations independence and venture planning autonomy does affect venture performance. Given the focus of the current research on venture planning autonomy, it was deemed important to demonstrate that any potentially observed effect of planning autonomy on venture performance exist above and beyond any interaction effects involving planning autonomy found in prior research. Accordingly both venture operations independence - operationalized using the scale proposed by Garrett and Covin (2015) - and the interaction term of venture operations independence $\times$ venture planning autonomy were included as controls in the current research.

Corporate-level controls included the parent corporation's sales revenue (logged), the number of parent corporation employees (also logged), the percentage of the parent corporation's sales revenue generated from the firm's largest industry, the number of new ventures started within the parent over the past 7 years, the extensiveness of the parent corporation's slack resources available for innovation activities, and the attractiveness of the parent corporation's core business prospects. The scales used to measure parent slack resources and attractiveness of core business prospects were developed and previously employed by Garrett and Covin (2015).

Table 1 provides the summary statistics for all research variables. Table 2 shows their zero-order correlations.

\subsection{Analytical techniques}

Because ICVs exist within parent corporations, a multilevel analytical technique was chosen. Specifically, hierarchical linear modeling (HLM) was employed to test the hypotheses. HLM is appropriate when researchers seek to understand the effects on particular outcome variables of "nested" factors operating at different levels of analysis (Raudenbush and Bryk 2002).

Three HLM models were run. In model 1, all control variables were included, with the exception of the 
interaction term created by multiplying planning autonomy by venture operations independence. As mentioned above, this interaction term needed to be assessed as a control variable. However, because the primary independent variable of the current research - venture planning autonomy-is a component of that interaction term, the main effect of venture planning autonomy on venture performance could not be determined had that interaction effect been included in the initial control variable equation. When the components of interaction terms are included in equations along with those interaction terms, the betas for the component terms represent conditional effects (the effects of those independent variables on the dependent variable when the other variable of the interaction is at its mean), not main effects. In short, model 1 was needed to assess support for hypotheses 1 . Model 2 then augmented the initial control model by including the interaction term planning autonomy $\times$ venture operations independence. Model 3

Table 1 Summary statistics

\begin{tabular}{|c|c|c|c|}
\hline Variable & Mean & S.D. & $\alpha$ \\
\hline Venture performance & 4.55 & 1.67 & .94 \\
\hline Venture planning autonomy & 4.49 & 1.20 & .87 \\
\hline Venture goal evolution & 3.86 & 1.40 & .79 \\
\hline Venture value proposition evolution & 4.19 & 1.46 & .77 \\
\hline Venture development stage & 2.13 & 0.79 & n.a. \\
\hline Venture age (years) & 3.13 & 2.12 & n.a. \\
\hline No. of venture employees & 20.71 & 51.48 & n.a. \\
\hline Market focus of venture & 2.72 & 0.72 & n.a. \\
\hline Product focus of venture & 2.95 & 0.69 & n.a. \\
\hline Environmental hostility & 3.84 & 1.00 & .68 \\
\hline Environmental dynamism & 3.97 & 1.01 & .74 \\
\hline Initial goal clarity & 5.63 & 1.05 & .81 \\
\hline Initial value proposition clarity & 5.60 & 1.10 & .74 \\
\hline Initial strategic asset endowment & 4.04 & 1.33 & .83 \\
\hline Venture operations independence & 4.15 & 1.61 & .78 \\
\hline Top management support & 5.95 & 1.01 & .87 \\
\hline Parent sales revenue $^{\mathrm{a}}$ & $5.45 \mathrm{~B}$ & 14.80B & n.a. \\
\hline No. of parent employees ${ }^{a}$ & 10,910 & 30,195 & n.a. \\
\hline Parent sales \%age from largest industry ${ }^{\mathrm{a}}$ & 61.82 & 27.92 & n.a. \\
\hline No. of ventures started-past 7 years $^{\mathrm{a}}$ & 9.61 & 18.71 & n.a. \\
\hline Parent slack resources ${ }^{\mathrm{a}}$ & 4.77 & 1.41 & .87 \\
\hline Attractiveness of core business prospects ${ }^{\mathrm{a}}$ & 5.05 & 1.19 & .79 \\
\hline
\end{tabular}

${ }^{a}$ These variables are measured at the corporate parent level, so $N=72$ (vs. 145 for the other variables which are measured at the venture level) adds the interaction terms needed to test hypotheses 2 and 3. These hypotheses suggest that the betas will be negative and significant in the case of the planning autonomy $\times$ goal evolution interaction term (hypothesis 2 ) and positive and significant in the case of the planning autonomy $\times$ value proposition interaction term (hypothesis 3).

Additional analyses were conducted to assess the possible significance of multicollinearity concerns when testing the hypotheses as well as the possible presence of sample selection bias. Specifically, SPSS was used to identify the variance inflation factors associated with the terms in the regression models. In all cases, the VIFs fell within the range proposed by Kutner et al. (2004), suggesting that multicollinearity is not problematic in the current research. The Heckman correction (Heckman 1979) procedure was used to assess whether sample-specific characteristics may have been affecting observed results. Specifically, data were collected on the sales revenue and number of corporate employees for all firms - both responding and nonresponding firmsincluded in the initial sample of 496 corporations. These data were used to compute an inverse Mills ratio which was included as an additional variable in the regression analyses. The inclusion of this ratio did not significantly affect the parameter estimates of any of the focal variables, suggesting that no bias exists with at least one of the core factors - namely, firm size — observed to differ between the responding and nonresponding firms.

Finally, the possible presence and significance of endogeneity within the structural model was assessed using the instrumental variable procedure recommended by Semadeni et al. (2014). The advocated procedure relies on an instrumental variable/two stage least squares (2SLS) approach to endogeneity assessment. We chose two instrumental variables using the criteria that, first, they were not correlated with our model's dependent variable and, second, that they were correlated with the potentially endogeneous variables. These two instruments were ICV initial strategic asset certainty and ICV learning proficiency. ICV initial strategic asset certainty-herein defined as the extent to which the venture's strategic assets (i.e., the key knowledge, technologies, competencies, or other resources needed to excel in the venture's business) were known to venture management at the venture's early development stagewas measured using a three-item scale developed expressly for this research $(\alpha=.90)$. This scale asked whether early in the venture's development, the most 


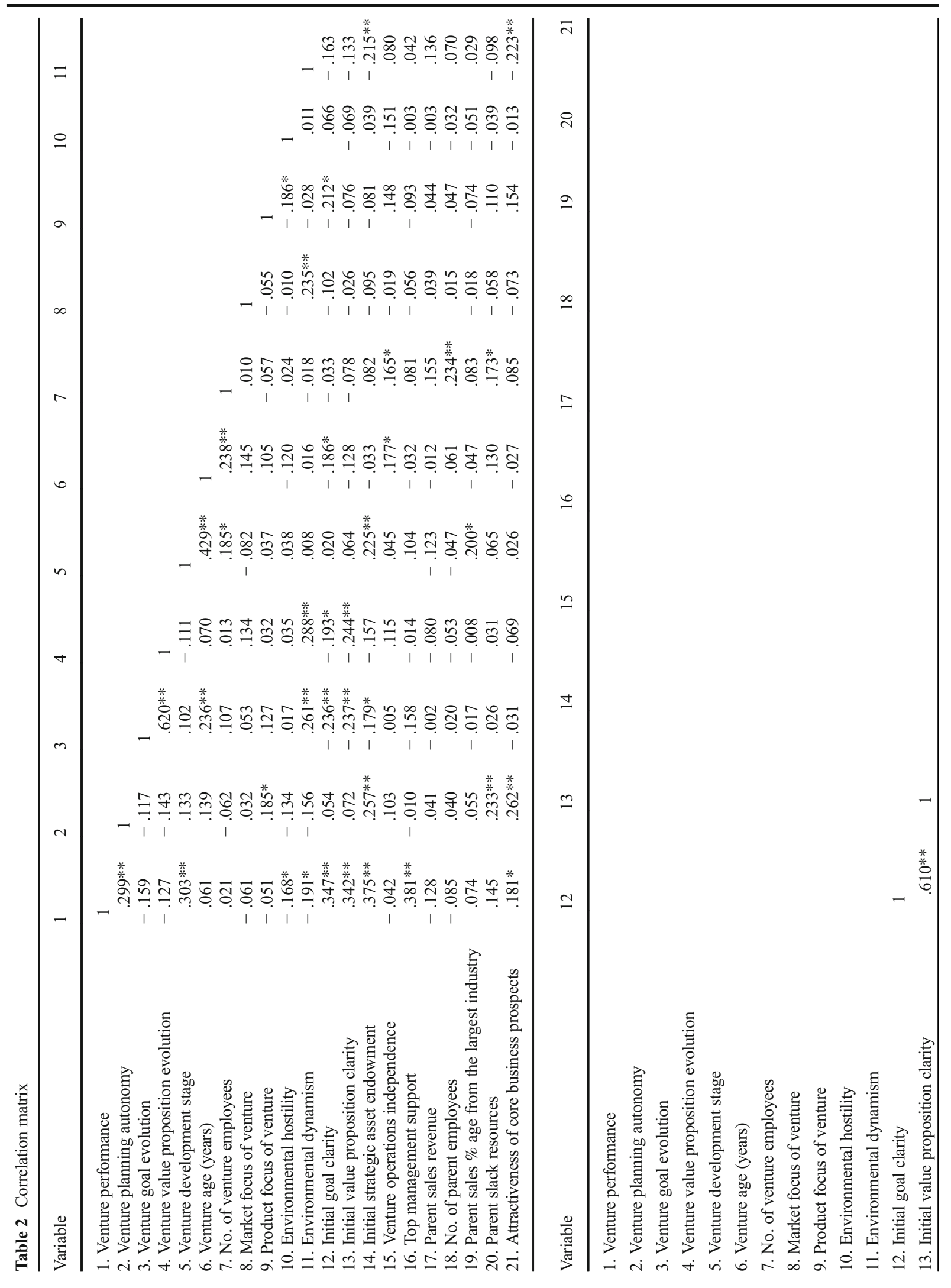




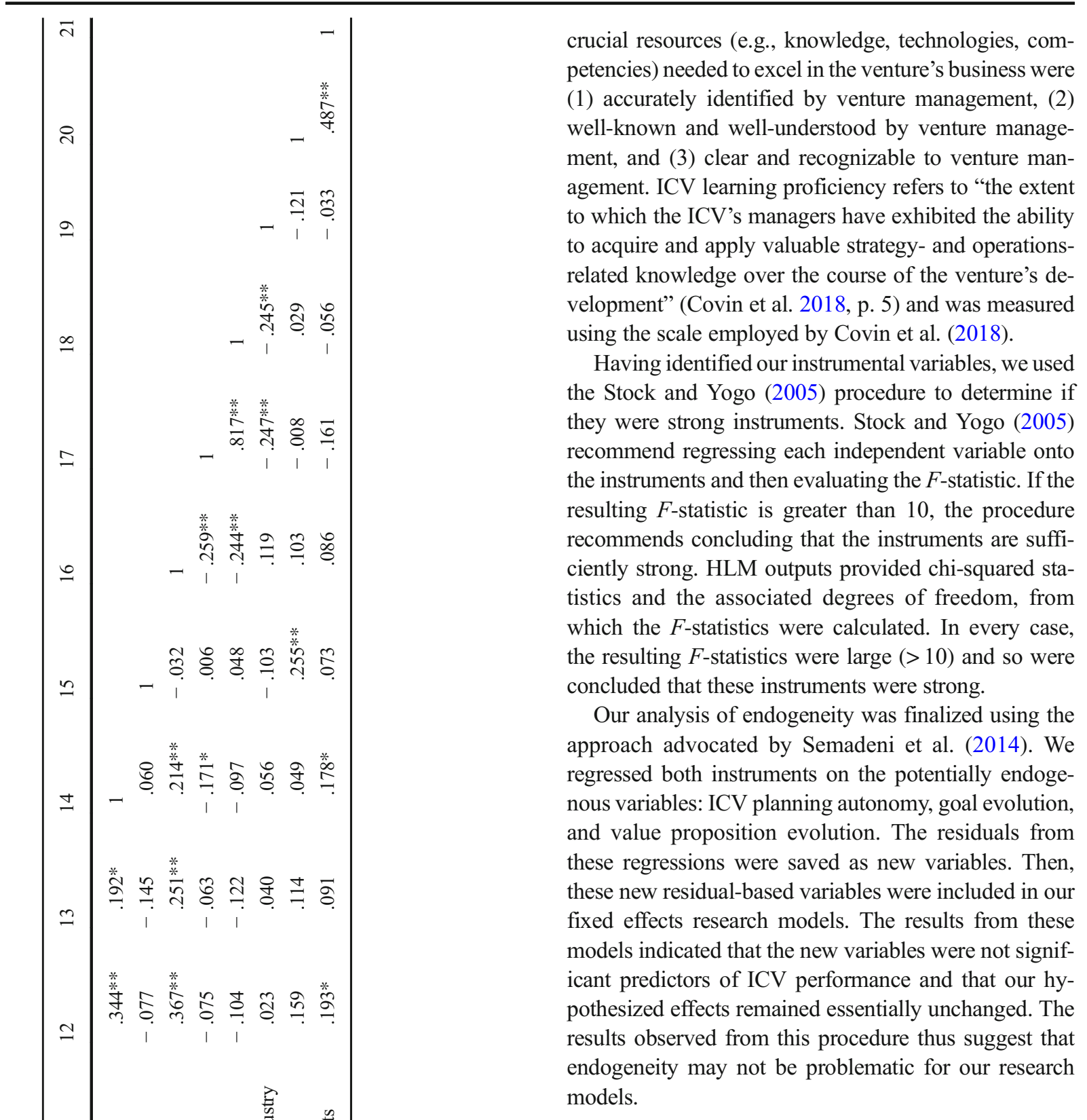

\section{Results}

The results of the HLM analysis are shown in Table 3. Consistent with hypothesis 1 , the beta for venture planning autonomy is positive, although the significance level is modest $(p<.10)$. Consistent with hypothesis 2 , the planning autonomy $\times$ goal evolution interaction term has a negative and significant $(p<.05)$ beta. Finally, consistent with hypothesis 3 , the planning autonomy $\times$ 
value proposition interaction term has a positive and significant $(p<.01)$ beta.

To better depict and interpret the observed interaction effects, the results pertaining to hypotheses 2 and 3 were plotted in Figs. 1 and 2, respectively, with the high and low lines representing one standard deviation from the mean of the indicated variable. These figures demonstrate that for low levels of planning autonomy, little venture performance difference is associated with whether the venture has undergone low or high levels of both goal evolution and value proposition evolution. It is at high levels of venture planning autonomy that variations in these strategic evolution dimensions significantly affect venture performance.

\section{Discussion and conclusion}

\subsection{Research implications}

Results suggest that venture planning autonomy does in fact promote venture performance, consistent with the preponderance of evidence and argumentation on this matter. While the main effect of venture planning autonomy on venture performance was observed to be of only modest significance, it should be noted that the results are based on an arguably conservative analysis in which a number previously explored drivers of performance were treated as controls. (The zeroorder correlation between venture planning autonomy and venture performance is $r=.299(p<.01)$.) Still, the principal value added of the current research is its examination of the value of planning autonomy as a function of the types (i.e., goal related or value proposition related) and levels (low-to-high) of strategic evolution observed in ICVs.

Consideration of Fig. 1 leads to several conclusions. First, venture planning autonomy works best-i.e., is associated with the highest levels of venture performance-when venture goals remain consistent over the course of the ICV's development. Alternatively, it might be argued that when senior corporate-level managers are responsible for choosing stable goals, ICVs will realize relatively lower levels of performance. Thus, venture performance seems to be facilitated when goals that remain stable were identified and chosen by venture managers, not senior corporate-level managers.
When venture goals are changed over the course of the venture's development-i.e., when goal evolution is high - the current data suggest that it really does not matter in performance enhancing or reducing sense who made those changes. Venture managers may be no more or less adept than senior-level managers at choosing new venture goals that yield high performance.

Figure 2 suggests a somewhat different set of conclusions with respect to value proposition evolution. Specifically, unlike the case with scenarios of high goal evolution, the matter of who makes the decision to enact value proposition changes does affect venture performance. Results are consistent with the likelihood that successful, valueadded value proposition changes-i.e., those associated with high venture performance-are more likely to have been made by venture- than senior corporate-level managers. With respect to the "low value proposition evolution" scenario, one could potentially draw the conclusion from Fig. 2 that when value propositions are not changed, venture performance is highest when senior-level managers make those decisions favoring stability. However, an explanation of this result that is more consistent with prior theorizing is that if venture managers do not have the power to make changes to their ICVs' value propositions - that is, if planning autonomy is low-then those ventures will perform best if no value proposition changes are made.

When contemplatings these results, it is useful to consider what goals and value propositions represent in a practical sense. Goals essentially define "what constitutes winning" for the ICV and value propositions specify "how the strategy game is played." With this in mind, the results of the current research suggest that venture planning autonomy matters (i.e., promotes venture performance) when what winning means is not redefined over the course of venture operations and when changes are made to how the game is played. Conversely, venture planning autonomy is not helpful to venture performance when what winning means is redefined over the course of venture operations and when changes are not made to how the game is played.

Collectively, the preceding suggests two primary research implications. First, when the game is changed and winning is redefined for the venture, it does not materially matter who established the new definition of winning - that is, who sets the new goals - there is going to be a learning curve. 
Table 3 Results of hierarchical linear modeling analysis

\begin{tabular}{|c|c|c|c|}
\hline \multirow[t]{2}{*}{ Variables } & \multicolumn{3}{|c|}{ DV is venture performance } \\
\hline & Model 1 & Model 2 & Model 3 \\
\hline Intercept & $\begin{array}{l}4.59 * * * \\
(0.14)\end{array}$ & $\begin{array}{l}4.59 * * * \\
(0.14)\end{array}$ & $\begin{array}{l}4.59 * * * \\
(0.14)\end{array}$ \\
\hline \multicolumn{4}{|l|}{ Controls and main effects } \\
\hline Venture development stage & $\begin{array}{l}0.54 * \\
(0.23)\end{array}$ & $\begin{array}{l}0.56^{*} \\
(0.23)\end{array}$ & $\begin{array}{l}0.70 * * \\
(0.24)\end{array}$ \\
\hline Venture age (years) & $\begin{array}{l}-0.11 \\
(0.10)\end{array}$ & $\begin{array}{l}-0.13 \\
(0.10)\end{array}$ & $\begin{array}{l}-0.16^{\dagger} \\
(0.09)\end{array}$ \\
\hline No. of venture employees & $\begin{array}{l}0.26 \\
(0.17)\end{array}$ & $\begin{array}{l}0.28^{\dagger} \\
(0.16)\end{array}$ & $\begin{array}{l}0.25^{\dagger} \\
(0.15)\end{array}$ \\
\hline Market focus of venture & $\begin{array}{l}0.28 \\
(0.19)\end{array}$ & $\begin{array}{l}0.34^{\dagger} \\
(0.19)\end{array}$ & $\begin{array}{l}0.33^{\dagger} \\
(0.20)\end{array}$ \\
\hline Product focus of venture & $\begin{array}{l}-0.02 \\
(0.29)\end{array}$ & $\begin{array}{l}-0.07 \\
(0.29)\end{array}$ & $\begin{array}{l}-0.07 \\
(0.28)\end{array}$ \\
\hline Environmental hostility & $\begin{array}{l}-0.52 * * \\
(0.15)\end{array}$ & $\begin{array}{l}-0.49 * * \\
(0.14)\end{array}$ & $\begin{array}{l}-0.44 * * \\
(0.14)\end{array}$ \\
\hline Environmental dynamism & $\begin{array}{l}-0.21 \\
(0.19)\end{array}$ & $\begin{array}{l}-0.25 \\
(0.19)\end{array}$ & $\begin{array}{l}-0.26 \\
(0.19)\end{array}$ \\
\hline Initial goal clarity & $\begin{array}{l}0.15 \\
(0.22)\end{array}$ & $\begin{array}{l}0.15 \\
(0.21)\end{array}$ & $\begin{array}{l}0.18 \\
(0.19)\end{array}$ \\
\hline Initial value proposition clarity & $\begin{array}{l}0.33 \\
(0.22)\end{array}$ & $\begin{array}{l}0.35^{\dagger} \\
(0.21)\end{array}$ & $\begin{array}{l}0.24 \\
(0.20)\end{array}$ \\
\hline $\begin{array}{l}\text { Initial strategic asset } \\
\text { endowment }\end{array}$ & $\begin{array}{l}0.22 * \\
(0.10)\end{array}$ & $\begin{array}{l}0.22 * \\
(0.10)\end{array}$ & $\begin{array}{l}0.20 * \\
(0.10)\end{array}$ \\
\hline $\begin{array}{l}\text { Venture operations } \\
\text { independence }\end{array}$ & $\begin{array}{l}-0.09 \\
(0.10)\end{array}$ & $\begin{array}{l}-0.12 \\
(0.09)\end{array}$ & $\begin{array}{l}-0.18^{*} \\
(0.08)\end{array}$ \\
\hline Top management support & $\begin{array}{l}0.19 \\
(0.19)\end{array}$ & $\begin{array}{l}0.18 \\
(0.18)\end{array}$ & $\begin{array}{l}0.20 \\
(0.17)\end{array}$ \\
\hline Parent sales revenue (ln) & $\begin{array}{l}-0.07 \\
(0.10)\end{array}$ & $\begin{array}{l}-0.07 \\
(0.10)\end{array}$ & $\begin{array}{l}-0.07 \\
(0.10)\end{array}$ \\
\hline No. of parent employees (ln) & $\begin{array}{l}0.05 \\
(0.13)\end{array}$ & $\begin{array}{l}0.05 \\
(0.13)\end{array}$ & $\begin{array}{l}0.05 \\
(0.13)\end{array}$ \\
\hline $\begin{array}{l}\text { Parent sales \% in largest } \\
\text { industry }\end{array}$ & $\begin{array}{l}0.01 \\
(0.00)\end{array}$ & $\begin{array}{l}0.01 \\
(0.00)\end{array}$ & $\begin{array}{l}0.01 \\
(0.00)\end{array}$ \\
\hline $\begin{array}{l}\text { No. of ventures started - past } \\
7 \text { years }\end{array}$ & $\begin{array}{l}0.00 \\
(0.00)\end{array}$ & $\begin{array}{l}0.00 \\
(0.00)\end{array}$ & $\begin{array}{l}0.00 \\
(0.00)\end{array}$ \\
\hline Venture planning autonomy & $\begin{array}{l}0.23^{\dagger} \\
(0.13)\end{array}$ & $\begin{array}{l}0.22 \\
(0.14)\end{array}$ & $\begin{array}{l}0.25^{*} \\
(0.12)\end{array}$ \\
\hline Venture goal evolution & $\begin{array}{l}-0.41^{* *} \\
(0.14)\end{array}$ & $\begin{array}{l}-0.37^{* *} \\
(0.12)\end{array}$ & $\begin{array}{l}-0.47 * * * \\
(0.12)\end{array}$ \\
\hline $\begin{array}{l}\text { Venture value proposition } \\
\text { evolution }\end{array}$ & $\begin{array}{l}0.19 \\
(0.13)\end{array}$ & $\begin{array}{l}0.19 \\
(0.13)\end{array}$ & $\begin{array}{l}0.31 * \\
(0.12)\end{array}$ \\
\hline $\begin{array}{l}\text { Venture value proposition } \\
\text { evolution squared }\end{array}$ & $\begin{array}{l}-0.18^{* *} \\
(0.06)\end{array}$ & $\begin{array}{l}-0.17 * * \\
(0.06)\end{array}$ & $\begin{array}{l}-0.11^{\dagger} \\
(0.06)\end{array}$ \\
\hline
\end{tabular}

Table 3 (continued)

\begin{tabular}{|c|c|c|c|}
\hline \multirow[t]{2}{*}{ Variables } & \multicolumn{3}{|c|}{ DV is venture performance } \\
\hline & Model 1 & Model 2 & Model 3 \\
\hline $\begin{array}{l}\text { Planning autonomy } \times \\
\text { operations independence }\end{array}$ & & $\begin{array}{l}0.15^{\dagger} \\
(0.09)\end{array}$ & $\begin{array}{l}0.17 * \\
(0.08)\end{array}$ \\
\hline \multicolumn{4}{|l|}{ Hypothesized interaction effects } \\
\hline $\begin{array}{l}\text { Planning autonomy } \times \text { goal } \\
\text { evolution }\end{array}$ & & & $\begin{array}{l}-0.24 * \\
(0.11)\end{array}$ \\
\hline $\begin{array}{l}\text { Planning autonomy } \times \text { value } \\
\text { proposition evolution }\end{array}$ & & & $\begin{array}{l}0.35^{* *} \\
(0.10)\end{array}$ \\
\hline
\end{tabular}

Under such circumstances, venture performance may suffer until effective means for playing the strategy game are identified and employed. Second and related to the preceding point, venture-level managers are likely better positioned than senior corporate-level managers to identify the means needed to meet venture objectives, regardless of the stability or lack thereof in those objectives. Moreover, if the means chosen to meet objectives are changed, those changes will most likely be successful-i.e., promote venture performance-if chosen by venture-level managers.

Notably, the current research builds upon prior observations in the internal corporate venturing literature suggesting the appropriateness of different roles for corporate- and venture-level managers. Long ago, George and MacMillan (1985) succinctly summarized conventional wisdom with their suggestion "let the senior management manage the woods, and the venture managers, the trees" (p. 91). These scholars noted that "the frequent interference of senior management in the individual ventures is something to be assiduously avoided. The basic challenge is to manage the venturing process, not the ventures themselves" (MacMillan and George 1985, p. 41). To this set of observations the current research adds that the types (i.e., goal related or value proposition related) and levels (low-to-high) of strategic evolution observed in ICVs affects the importance of venture planning being the responsibility of venture managers. 
Fig. 1 Moderating effect of goal evolution

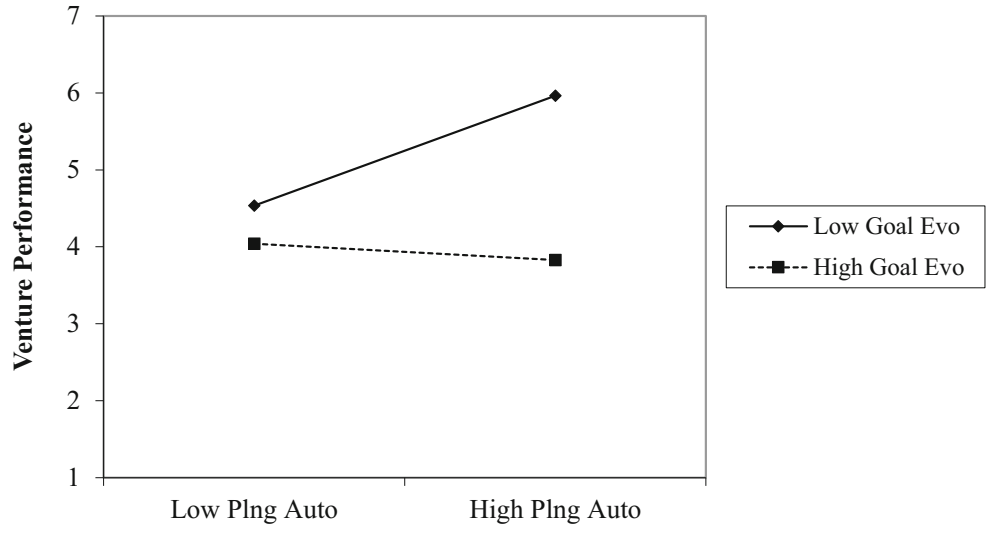

\subsection{Research limitations}

The research findings should be considered in light of the study's limitations, two of which are particularly salient. First, a direct relationship is assumed to exist between the level of venture planning autonomy observed and who made any changes - or did not make any changes - to the ICV's goals and value propositions. For example, it is assumed that when venture planning autonomy is high and venture goals remain stable, venture manager preference is the reason those goals have remained stable. Similarly, it is assumed that when venture planning autonomy is high and venture goals have been changed, venture manager preference is the reason those goals have been changed. This assumption is made because the planning autonomy scale explicitly references and identifies who establishes or makes changes to the venture's goals and strategies-that is, senior corporate-level management, venture-level management, or some combination thereof representing scenarios of shared responsibility. While the rationale for this assumption appears solid, the possibility cannot be ruled out that changes in ICV goals or value propositions-or the decision to sustain existing goals and value propositions - may occasionally occur if parties acquiesce to the others' preferences even though those initial parties are generally responsible for those decisions.

A second research limitation is the fact that the degree of venture planning autonomy afforded ICVs could conceivably change over the course of those ICVs' development, yet such change was not assessed in the current research. Encouragingly, ANOVA results revealed there are no overall differences $(p>.10)$ in the level of planning autonomy reported by ICVs operating in different development stages, nor are there differences in level of planning autonomy between any of the pairs of stages (i.e., early vs. middle, early vs. established, middle vs. established). Still, the overall
Fig. 2 Moderating effect of value proposition evolution

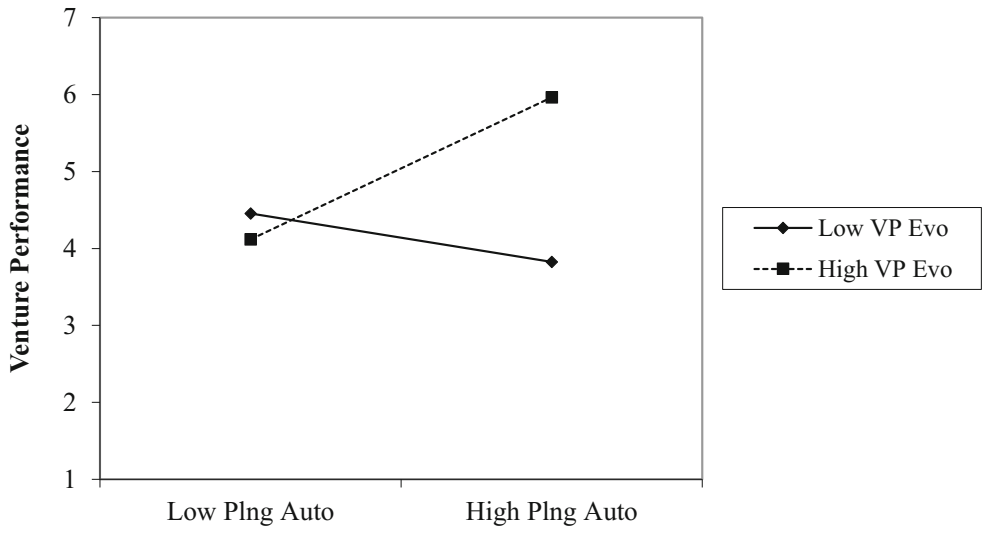


and pairwise statistics do not capture potentially significant planning autonomy changes that may occur for individual ICVs over time.

\subsection{Future research directions}

The results and implications of the current study suggest several promising areas for future research. For example, "air cover" is often needed to shield ICVs from deleterious influences operating within the corporate environment (McGrath et al. 2006). Corporate parents can provide such air cover. As ICVs mature, their demonstrated performance often makes them less vulnerable to such factors as political whims and inappropriate comparisons, making air cover less important to venture success (Garvin and Levesque 2006). Corporate parents that can well manage the "newstream-to-mainstream" transition will be adding value to their ventures (Kanter 1989). In short, it is plausible that the ways in which corporate parents add value to their ICVs will evolve as those ventures develop. Following from the aforementioned research limitation, research that elucidates any changes in the importance of venture planning autonomy (or other manifestations of the presence or absence of corporate management oversight) across the venture development stages will be of great theoretical and practical significance.
Second, future research should explore the role of corporate parents' unique organizational circumstances as a determinant of the likelihood and manner in which corporate-level managers will or should become involved in the strategic management of their firms' ICVs. For example, anecdotal research suggests that corporate-level interest in start-up businesses is driven by the amount of unabsorbed slack-i.e., spare resources beyond those needed to sustain the current business - possessed by the parent (Burgelman and Valikangas 2005). As such, parents with greater slack resources may be more willing to invest in corporate start-ups without feeling the need to closely oversee or control the affairs of those ventures. A challenge to parent corporations is knowing how to manage ICVs that may be variously central to the firms' strategic interests. When ICVs are seen as the most promising options for growth and profitability, corporate-level managers may be inclined to lean on them too heavily as bases for increasing overall corporate performance, intervening in or micro-managing their operations to insure that promising opportunities are not wasted. Research is encouraged that explores relationships between venture planning autonomy, indicators of the prioritization accorded new ventures within corporate business portfolios, and ICV performance.

\section{Appendix 1}

Table 4 Internal corporate venture identification matrix

\begin{tabular}{|c|c|c|c|c|c|}
\hline \multirow[t]{6}{*}{$\begin{array}{l}\text { Market focus of } \\
\text { the venture }\end{array}$} & $\begin{array}{l}\text { Market creation } \\
\text { (new to "world") }\end{array}$ & $\begin{array}{l}\text { New business } \\
\quad(\mathrm{N}=2)\end{array}$ & $\begin{array}{l}\text { New business } \\
\qquad(N=3)\end{array}$ & $\begin{array}{l}\text { New business } \\
\quad(N=7)\end{array}$ & $\begin{array}{l}\text { New business } \\
\quad(N=10)\end{array}$ \\
\hline & $\begin{array}{l}\text { New market for the } \\
\text { Corp. }\end{array}$ & $\begin{array}{l}\text { Major market } \\
\text { development }\end{array}$ & $\begin{array}{l}\text { New business } \\
\quad(N=29)\end{array}$ & $\begin{array}{l}\text { New business } \\
\quad(N=18)\end{array}$ & $\begin{array}{l}\text { New business } \\
\quad(N=15)\end{array}$ \\
\hline & $\begin{array}{l}\text { Extension of current } \\
\text { market }\end{array}$ & $\begin{array}{l}\text { Minor market } \\
\text { development }\end{array}$ & $\begin{array}{l}\text { Minor product-market } \\
\text { development }\end{array}$ & $\begin{array}{l}\text { New business } \\
\quad(N=57)\end{array}$ & $\begin{array}{l}\text { New business } \\
\qquad(N=3)\end{array}$ \\
\hline & $\begin{array}{l}\text { Current market of the } \\
\text { Corp. }\end{array}$ & Market penetration & $\begin{array}{l}\text { Minor product } \\
\text { development }\end{array}$ & $\begin{array}{l}\text { Major product } \\
\text { development }\end{array}$ & $\begin{array}{l}\text { New business } \\
\qquad(N=1)\end{array}$ \\
\hline & & $\begin{array}{l}\text { Current product of the } \\
\text { Corp. }\end{array}$ & $\begin{array}{l}\text { Extension of current } \\
\text { product }\end{array}$ & $\begin{array}{l}\text { New product for } \\
\text { the Corp. in } \\
\text { current industry }\end{array}$ & $\begin{array}{l}\text { New product for the } \\
\text { Corp. in new industry } \\
\text { (i.e., diversification) }\end{array}$ \\
\hline & Product focus of the ve & ature & & & \\
\hline
\end{tabular}




\section{Appendix 2}

\section{Measures}

Unless otherwise indicated, the scale items were assessed using 7-point scales ranging from "strongly disagree" (=1) to "strongly agree" (=7).

Venture performance: Please respond to the statements below in reference to the venture in question.
Because defunct ventures will have performed variously well prior to their expiration/termination, I am asking you to complete the following scale even if the venture in question is no longer operating. If the venture is defunct, please indicate how you would have evaluated the venture at the time of its expiration/termination. Indicate your level of agreement (by circling the appropriate number) with each statement based on the following scale:

\begin{tabular}{lllllll}
\hline Strongly disagree & Disagree & Slightly disagree & Neutral & Slightly agree & Agree & Strongly agree \\
1 & 2 & 3 & 4 & 5 & 6 & 7 \\
\hline
\end{tabular}

- This venture generally meets (or met) the expectations of the parent corporation.

- The parent corporation views (or viewed) this venture as being successful, overall.

- The parent corporation believes (or believed) that this venture achieved its key milestones (i.e., events crucial to the venture's successful development) on schedule for each stage of its development.

- This venture is performing (or performed) well in terms of the criteria (e.g., financial returns, market share, learning/ acquisition of new knowledge) the parent corporation considers (or considered) important to the venture's success.

Venture planning autonomy

\begin{tabular}{|c|c|c|c|c|c|c|}
\hline $\begin{array}{l}\text { The sole } \\
\text { responsibility of a } \\
\text { higher level(s) of } \\
\text { authority within } \\
\text { the corporation }\end{array}$ & & & $\begin{array}{l}\text { Equally the } \\
\text { responsibility of a } \\
\text { higher level(s) of } \\
\text { authority within the } \\
\text { corporation and } \\
\text { venture-level } \\
\text { management }\end{array}$ & & & $\begin{array}{l}\text { The sole } \\
\text { responsibility of } \\
\text { venture-level } \\
\text { management }\end{array}$ \\
\hline 1 & 2 & 3 & 4 & 5 & 6 & 7 \\
\hline
\end{tabular}

Who is (was) responsible for each of the following venture activities and decision areas?

- Setting of the venture's goals

- Establishment of a timetable (if applicable) for the achievement of the venture's goals

- Choice of formal criteria used to measure the venture's performance
- Identification of event milestones (if any) used to assess the venture's progress

- Formulation of the venture's business strategy

- Decision to change (if necessary) the venture's business strategy

Venture goal evolution: (1) The venture's strategic objectives have (had) evolved considerably over time in accommodation of new knowledge acquired in the 
course of the venture's operations. (2) The focus of the venture's objectives has (had) changed considerably as the venture has (had) developed. (3) The venture's objectives have (had) remained constant from the time they were initially set/established (reverse-coded item).

Venture value proposition evolution: (1) The venture's value proposition-i.e., the intended basis on which it would appeal to the market — has (had) evolved considerably over time in accommodation of new knowledge acquired in the course of the venture's operations. (2) The focus of the venture's value proposition has (had) changed considerably as the venture has (had) developed. (3) The venture's value proposition has (had) remained constant from the time it was initially set/ established (reverse-coded item).

\section{References}

Bhide, A. (1994). How entrepreneurs craft strategies that work. Harvard Business Review, 72(2), 150-161.

Bhide, A. (2000). The origin and evolution of new businesses. New York: Oxford University Press.

Birkinshaw, J., \& Hill, S. A. (2005). Corporate venturing units: vehicles for strategic success in the new Europe. Organizational Dynamics, 34(3), 247-257.

Block, Z., \& MacMillan, I. (1993). Corporate venturing. Boston: Harvard Business School Press.

Bouchard, V., \& Fayolle, A. (2018). Corporate entrepreneurship. New York: Routledge.

Burgelman, R. A. (1988). Strategy making as a social learning process: the case of internal corporate venturing. Interfaces, 18(3), 74-85.

Burgelman, R. A., \& Valikangas, L. (2005). Managing internal corporate venturing cycles. MIT Sloan Management Review, 46(4), 26-34.

Covin, J. G., Slevin, D. P., \& Heeley, M. B. (2000). Pioneers and followers: competitive tactics, environment, and firm growth. Journal of Business Venturing, 15(2), 175-210.

Covin, J. G., Garrett, R. P., Jr., Kuratko, D. F., \& Shepherd, D. A. (2015). Value proposition evolution and the performance of internal corporate ventures. Journal of Business Venturing, 30(5), 749-774.

Covin, J. G., Garrett, R. P., Jr., Gupta, J. P., Kuratko, D. F., \& Shepherd, D. A. (2018). The interdependence of planning and learning among internal corporate ventures. Entrepreneurship Theory and Practice, 42(4), 537-570.

Gard, J., Katzy, B., Andersen, T. J., Baltes, G. H., \& Gasser, T. (2018). Corporate venture management in small-medium sized enterprise: the roles and effects of autonomy and corporate policy. In The 24th ICE/IEEE International Technology Management Conference.

Garrett, R. P., Jr., \& Covin, J. G. (2015). Internal corporate venture operations independence and performance: a knowledgebased perspective. Entrepreneurship Theory and Practice, 39(4), 763-790.
Garrett, R. P., Jr., \& Neubaum, D. O. (2013). Top management support and initial strategic assets: a dependency model for internal corporate venture performance. Journal of Product Innovation Management, 30(5), 896-915.

Garud, R., \& Van De Ven, A. H. (1992). An empirical evaluation of the internal corporate venturing process. Strategic Management Journal, 13(S1), 93-109.

Garvin, D. A., \& Levesque, L. C. (2006). Meeting the challenge of corporate entrepreneurship. Harvard Business Review, 84(10), 102-112.

George, R., \& MacMillan, I. C. (1985). Corporate venturing: venture management challenges. Journal of Business Strategy, 6(2), 85-91.

Ginsberg, A., \& Hay, M. (1994). Confronting the challenges of corporate entrepreneurship. European Management Journal, 12(4), 382-389.

Glaister, K. W., Husan, R., \& Buckley, P. J. (2003). Decisionmaking autonomy in UK international equity joint ventures. British Journal of Management, 14(4), 305-322.

Heckman, J. (1979). Sample selection bias as a specification error. Econometrica, 47(1), 153-161.

Hill, S. A., \& Georgoulas, S. (2016). Internal corporate venturing: a review of (almost) five decades of literature. In S. A. Zahra, J. Hayton, \& D. O. Neubaum (Eds.), Handbook of corporate entrepreneurship (pp. 13-63). Cheltenham: Edward Elgar.

Johnson, K. L. (2005). Predicting internal corporate venture performance: process, resource, strategic and structural considerations. Unpublished dissertation, Bloomington, IN: Indiana University.

Johnson, K. L. (2012). The role of structural and planning autonomy in the performance of internal corporate ventures. Journal of Small Business Management, 50(3), 469-497.

Kanter, R. M. (1989). Swimming in newstreams: mastering innovation dilemmas. California Management Review, 31(4), 4569.

Kiss, A. N., \& Barr, P. S. (2015). New venture strategic adaptation: the interplay of belief structures and industry context. Strategic Management Journal, 36(8), 1245-1263.

Klein, H. J., Wesson, M. J., Hollenbeck, J. R., \& Alge, B. J. (1999). Goal commitment and the goal-setting process: conceptual clarification and empirical synthesis. Journal of Applied Psychology, 84(6), 885.

Kuratko, D. F., Covin, J. G., \& Garrett, R. P., Jr. (2009). Corporate venturing: insights from actual performance. Business Horizons, 52(5), 459-467.

Kutner, M. H., Nachtsheim, C. J., \& Neter, J. (2004). Applied linear regression models. New York: McGraw-Hill Irwin.

Leten, B., \& Van Dyck, W. (2012). Corporate venturing: strategies and success factors. Review of Business and Economic Literature, 57(4), 243-256.

Locke, E. A., Latham, G. P., \& Erez, M. (1988). The determinants of goal commitment. Academy of Management Review, 13(1), 23-39.

Lynn, G. S., Reilly, R. R., \& Akgun, A. E. (2000). Knowledge management in new product teams: practices and outcomes. IEEE Transactions on Engineering Management, 47(2), 221-231.

MacMillan, I. C., \& George, R. (1985). Corporate venturing: challenges for senior managers. Journal of Business Strategy, 5(3), 34-43. 
McGrath, R. G. (1995). Advantage from adversity: learning from disappointment in internal corporate ventures. Journal of Business Venturing, 10(2), 121-142.

McGrath, R. G. (2001). Exploratory learning, innovative capacity, and managerial oversight. Academy of Management Journal, 44(1), 118-131.

McGrath, R. G., Keil, T., \& Tukiainen, T. (2006). Extracting value from corporate venturing. MIT Sloan Management Review, 48(1), 50-56.

Miller, D., \& Friesen, P. H. (1982). Innovation in conservative and entrepreneurial firms: two models of strategic momentum. Strategic Management Journal, 3(1), 1-25.

Morris, M. H., Kuratko, D. F., \& Covin, J. G. (2011). Corporate entrepreneurship \& innovation (3rd ed.). Mason: Cengage/ Southwestern Publishing.

Osterwalder, A., Pigneur, Y., Bernarda, G., \& Smith, A. (2014). Value proposition design: how to create products and services customers want. New York: John Wiley \& Sons.

Payne, A., Frow, P., \& Egger, A. (2017). The customer value proposition: evolution, development, and application in marketing. Journal of the Academy of Marketing Science, 45(4), 467-489.

Piercy, N. F. (2016). Market-led strategic change: transforming the process of going to market. London: Routledge.

Raudenbush, S., \& Bryk, A. (2002). Hierarchical linear models (2nd ed.). Thousand Oaks: Sage Publications.

Semadeni, M., Withers, M. C., \& Certo, S. T. (2014). The perils of endogeneity and instrumental variables in strategy research: understanding through simulations. Strategic Management Journal, 35(7), 1070-1079.

Simon, M., Houghton, S. M., \& Gurney, J. (1999). Succeeding at internal corporate venturing: roles needed to balance autonomy and control. Journal of Applied Management Studies, $8(2), 145$.

Stock, J. H., \& Yogo, M. (2005). Testing for weak instruments in linear IV regressions. In D. W. K. Andrews \& J. H. Stock (Eds.), Identification and inference for econometric models (pp. 80-108). Cambridge: Cambridge University Press.

Sykes, H. B. (1986). The anatomy of a corporate venturing program: factors influencing success. Journal of Business Venturing, 1(3), 275-293.

Thornhill, S., \& Amit, R. (2001). A dynamic perspective of internal fit in corporate venturing. Journal of Business Venturing, 16(1), 25-50.

Weiss, L. A. (1981). Sloan Management Review 23(1), 37-53.

Wiklund, J., Baker, T., \& Shepherd, D. (2010). The age-effect of financial indicators as buffers against the liability of newness. Journal of Business Venturing, 25(4), 423-437.

Zook, C., Allen, J., Earle, N., \& Keen, P. (2001). Profit from the core. Boston: Harvard Business School Press.

Publisher's note Springer Nature remains neutral with regard to jurisdictional claims in published maps and institutional affiliations. 